New Zealand journal of industrial relations, 1987, 12, 187-197

\title{
The unintended consequences of the arbitration system
}

\author{
Pat Walsh* and Geoff Fougere**
}

Eight years ago Jim Holt, Erik Olssen and the two authors of this paper met together over a long and relaxed dinner. Jim was in Christchurch to work on the McCullough diaries, as it turned out, an important source in writing. Compulsory arbitration in New Zealand. Erik Olssen was doing parallel work on the Red Feds. Pat Walsh, as an analyst of industrial relations had a direct interest in labour history while Geoff Fougere's interest lay more generally in New Zealand political economy. At different times, all four of us had been graduate students in the United States. The mix of shared and differing interests made for a pleasurable evening. Talk ranged widely over issues in New Zealand society, relationships between social science and history and the peculiarities of New Zealand academic life. In its own way, this paper is a continuation of that conversation.

Jim's article, "The political origins of compulsory arbitration in New Zealand: a comparison with Great Britain' (Holt, 1976) had intrigued and excited us. It often seems to social scientists that historians have a love affair with narrative which precludes the search for causal and structural explanations. But here was an analysis that explicitly delineated the roles of state and societal actors and used comparison to explain why compulsory arbitration had been introduced into New Zealand but not in Britain. As such it remains the definitive account. The book successfully carries the argument further while developing its substance.

In dealing with the book, we want to recast Holt's account in a more explicitly theoretical way. Our principle concerns are the relations among state officials and politicians, and class and sectoral organizations of workers, employers and farmers.' We will use Holt's account to show how, in certain circumstances, states can decisively structure the resources available for the mobilisation of interests in civil society and how this in turn shapes state policy and organization. We will also comment on the interplay of narrative and analysis in the explanation of events that happen over time.

Social scientists and historians have again become interested in the question of state structure, state actors and state capacities. This interest has recast dominant theories - marxist and liberal both - and revived neglected traditions of state centred analysis, drawing particularly on Weber, Hintze and de Tocqueville. ${ }^{2}$ In contrast to their marxist and liberal alternatives, state centred approaches grant the possibility of autonomous action to state officials. They also attempt to analyse the impact of state structure on the formation and development of social groups. In this view, as Skocpol $(1985$, p. 21$)$ puts it:

states matter not simply because of the goal oriented activities of state officials. They matter because their organizational configurations along with their overall patterns of activity affect political culture, encourage some kinds of group formation and collective political actions (but not others) and make possible the raising of certain political issues (but not others) .... the structures and activities of states unintentionally influence the formation of groups and the political capacities, ideas and demands of various sectors of society.

* Senior Lecturer Industrial Relations Centre, Victoria University of Wellington.

** Senior Lecturer, Department of Community Health, Wellington School of Medicine.

This paper was written jointly; the order of authorship was determined by flipping a coin.

1 In looking at state officials we focus upon the members of the Arbitration Court. Also important were Department of Labour officials. On this see, Williams (1977). 
In discussing Holt's book we will, like him, concentrate equally on the 'goal oriented activities of state officials' in the creation and maintenance of the arbitration system and on its unintended influence on, 'the formation of groups and the political capacities, ideas and demands of various sectors of society', and in turn the latter's influence on state officials and state structure.

\section{Creating the system}

We begin not with Holt, but with the political scientist, Francis Castles. In a provocative but historically flawed book. Castles makes compulsory arbitration of pivotal importance to the development of social and economic policy in New Zealand and Australia (Castles, 1985). According to Castles, the arbitration system shaped the social and economic policy preferences of unions in each country. In turn this contributed to the particular trajectory of Australasian welfare state development: policy leadership around the turn of the century, divergent paths in the 1930s and the shared status of welfare state laggards in the period after the second world war. (The latter characterisation is entirely accurate but not widely recognised in New Zealand - as shown by contemporary debate on the future of the welfare state).

Castles' analysis of the political and industrial coalitions that led to the IC\&A Act differs strikingly from Holt's. According to Castles, the period 1890-1910 was characterised by working class strength outside of parliament but limited influence within Parliament. ${ }^{4}$ Holt's argument is the reverse. According to Holt, unions had always been weakly organized except for a brief flurry between 1889 and 1890. Defeat in the Maritime Strike confirmed rather than contradicted this situation. Industrial weakness meant that unions saw arbitration as offering them benefits they could not win through their own industrial efforts but could secure through their coalition partnership within the Liberal government. Thus it was the precise mix of industrial weakness coupled with political influence that explains the union stance - a configuration that Castles explicitly rules out as, 'most improbable on theoretical grounds' (1985, p. 6).

Castles and Holt are in agreement in their discussion of potential sources of parliamentary and extra-parliamentary opposition to compulsory arbitration. According to both, the divergent stances of rural and urban property owners deprived conservative critics of their ability to block the Liberals' progressive legislation, including the IC\&A Act. To urban employers, the Act threatened to undermine their shop-floor power, so clearly revealed in the Maritime Strike and its aftermath. However this shop-floor power could not be turned into political influence. This was because. Holt argues, employers were unable to make an alliance with rural interests and hence unable to derail the legislation.

Why did farmers not oppose arbitration - especially seeing that they were later to become vehement critics and, as we will show, were at every point crucial to the development of the arbitration system? There is no wholly satisfactory account. Holt claims that representatives of rural electorates believed that the system would not apply to farm labour and hence aquiesced in the passing of the Act. Martin disagrees (Martin, 1987). His account of the parliamentary debates suggests that rural representatives did believe that it would apply to their constituents. But it is then unclear from Martin's account why they did not oppose the measure.

However, there is more to the passing of the legislation than the vector of class and sectoral interests. As we argued above, states matter - in the first place because of the 'goal oriented activities of state officials' and in the second place, because 'their organizational configura-

In a forthcoming paper, we intend to examine critically Castles' theory of welfare state development in Australia and New Zealand.

Castles does acknowledge the links between trade unions and the Liberal government. links central to Holt's account, but the thrust of his analysis is to discount their significance and to give explanatory priority to unions' industrial strength.

$5 \quad$ We suspect that further research will suggest a divergence between large landowners. who employed a considerable amount of labour and family farmers who did not. Only the latter were critical to the Lib-Lab coalition and it was their acquiescence which enabled the arbitration legislation to become law. The large landowners opposed the legislation, vainly in the lower house, but successfully in the upper, until robbed of their majority there too. 
tions ... encourage some kinds of group formation and collective political actions (but not others) and make possible the raising of certain political issues (but not others) '(Skocpol, 1985 p. 21). Whereas Castles' analysis neglects both of these dimensions, Holt takes seriously the first argument but underplays the second. Like other observers. Holt emphasises the importance of Reeves in initiating the legislation and in getting it passed. The novelty of his account is in showing that Reeves' success depended not simply on his energy and parliamentary skill but also on the prevailing configuration of class and sectoral interests and capacities. The formation of this configuration and the translation of the interest and capacities it represented into political power depended however, on aspects of state structure little examined by Holt. The creation of a party able to command majorities in parliament and based on programmatic appeals to a fully enfranchised electorate was new. ${ }^{6}$ This made possible the systematic working through of a legislative agenda by the Liberal government. The content of the agenda in turn, depended on the character of the coalition that formed the Liberal government. This coalition determined how interests outside of parliament were aggregated and balanced within parliament: the discounting of the industrial power of employers, the balancing of the industrial weakness of the unions with political influence, and the neutralising of the opposition that might have been expected from some rural MPs. This was perhaps as much due to their desire to continue as participants in the coalition, as to their ignorance of the possible impact of the IC\&A Act on rural labour or the gains they might have hoped for from industrial peace. In the Liberals' first term labour MPs did not oppose land legislation; in the second, rural MPs did not oppose compulsory arbitration.

\title{
The maintenance of the system
}

Making sense of the arbitration system requires making sense of what we call, 'Holt's paradox: that a system set up to solve one set of problems flourished by solving completely different ones. Reeves principle intention in sponsoring compulsory arbitration was to stop strikes and lock-outs. The use of conciliation boards and the Arbitration Court was intended to provide a rational means of dispute settlement, a civilised alternative to the atavistic approaches of Britain and other countries. It is true that there were no strikes or lock outs until 1906; but the industrial weakness of the unions made this a likely outcome even in the absence of the arbitration system. Indeed strikes resumed again once some unions felt strong enough to engage in direct bargaining. More to the point, the conflicts that the Court resolved were for the most part of the system's own making. As Holt puts it:

\begin{abstract}
the arbitration system system. in its early years, only occasionally provided the means of settling disputes which had arisen from a bargaining situation or a threatened strike or lockout. In most cases the unions activated the arbitration machinery in order to initiate formal proceedings with employers and often they only existed for that purpose. In a sense the arbitration system created the disputes it then settled (p. 42).
\end{abstract}

As this quotation suggests, the arbitration system also largely created the organizations of unions and employers who brought disputes to the court for its resolution. For the most part these were not existing organizations but new ones, created to fit the Act's requirements for registration. Such organizations did not have to adapt to the arbitration system, but grew from it and with it. In Holt's words:

A new variety of trade unionism had appeared in New Zealand which owed its very existence to the Arbitration Act and which depended on the coercive power of the state to achieve its ends. The Arbitration Court had become a tribunal charged not only with resolving conflicts but with fixing minimum wages, maximum hours and conditions of employment in evergrowing areas of the private sector. None of this could have happened without Reeve's Act and in this sense Reeve's experiment was a success, but it was the kind of success achieved by the hunter who went out seeking wild boar and came back proudly bearing a stag (p. 53 ).

How the Liberals created and maintained their parliamentary and electoral coalition has been little explored. Lipson (1948), shows the striking stability of cabinets after 1891 - but does not document in any detail how this was achieved. Other commentators are equally reticent (see Richardson. 1981. Sinclair. 1965). 


\section{The nature of the stag: organizations and their strategies}

How to go out for a boar and come back with a stag? Reeves seems to have thought that compulsory arbitration would amend but not transform the pattern of industrial relations. The state would rule out some forms of influence and limit some conflicts. It would not however fundamentally alter the dynamics of the existing system: the parties would still settle most disputes by direct collective bargaining, underpinned by their respective levels of market power. Instead, the development of the arbitration system fundamentally transformed the nature and practice of industrial relations.

Side by side with the existing market based system, compulsory arbitration created an alternate ecology, based on the administrative and coercive machinery of the state. This alternate ecology provided new resources for the organization of employer and union groups. for the definition of interests, the wielding of influence, the framing of conflicts and the enforcement of their resolution. The processes it set in motion were embedded in time. Participants discovered, not immediately, but in an unfolding pattern, the resources made available by the system and the uses to which they could be put. This unfolding, and the interplay between the arbitration system, the market and political parties, generates and explains the course of industrial relations in New Zealand between 1894 and 1932 - and for a long time thereafter.

From 1894, union organizers and employers had available two broad strategies for achieving their goals. As before, they could pursue a labour market strategy based on the threat of strike or lockout and aimed at settling wages and conditions by direct negotiation. Alternately they could pursue a court-based strategy, arising from the Court's recognition of the parties and based on the presentation of evidence before a tribunal charged with making binding determinations on wages and conditions. Which strategy seemed most attractive varied for the parties over time: weakness in the labour market could be balanced by the standing given by the Court while labour market strength encouraged the avoidance of the Court and reliance on direct bargaining. The choice of strategies was of interest not only to the parties themselves however, but also to outsiders: politicians, state officials, the public at large, and especially farmers, who believed their own interests damaged or enhanced in the process. Their choices, as much of those of the direct participants, helped to determine the outcomes of the strategies chosen.

\section{Unions}

Normally, unions are reliant on the use of market power to win concessions: employers are forced to recognise and bargain with unions on threat of strikes. Creating a credible strike threat depends upon the degree to which union members can be mobilised for co-ordinated action that threatens employer interests. As many theorists and many organizers have noted, trade unions encounter numerous obstacles in achieving this level of organization (Olson, 1965; Offe, 1981).

The attraction of the arbitration system was that it made these considerations largely irrelevant to trade unions who wished to work within it. The system guaranteed unions employer recognition, provided a bargaining forum in which employers were compelled to appear, and enforced minimum wages and conditions according to the Court's determinations. All that was required was registration under the Act, application to the Court for an award and observance of the procedures for conciliation and arbitration. Any seven (later 15) workers could form a union and activate this process. As we have noted, the great bulk of unions registered under the Act were formed precisely to take advantage of its provisions, their officials more at home in the courtroom than on the picket line.

But circumstances change and with them the attraction of alternate strategies to unionists. In the wake of the Maritime Strike unions were for the most part weak, disorganized or nonexistent. But after the turn of the century, and especially after 1905 (Olssen, 1987), the fortunes of many unions revived and the levels of unionisation, particularly of unskilled workers rapidly increased. If the arbitration system made organizing easy, it also, it was increasingly 
argued. offered few gains to workers. Fewer, anyway, than they could win through direct bargaining with employers. The rewards of opting out. as opposed to staying within the system. were not however evenly spread. All unions found their bargaining power affected by the business cycle. But within this broad constraint, unions differed markedly in the levels of organization they could muster and the strategic power given to them by their position in the economy. For some unions their best strategy would always be to stick with the arbitration system, while for others innovations in organization and tight labour markets would provide pressing incentives for opting out in favour of direct bargaining.

The likelihood of staying within the arbitration system as opposed to opting out was not however simply a matter of choice coupled with the appropriate pattern of incentives. Unions organized under the rubric of the arbitration system were more its dependent clients than its independent judges. The internal organization required for the effective utilisation of the arbitration system s procedures did not provide a basis for the mass mobilisation of workers and vice-versa. Unions could not slide easily from one choice of strategy to another. Their pattern of organization represented a form of sunk costs which importantly constrained their choices. Even when the arbitration system was not delivering, it could count on the grudging loyalty of such unions, sometimes coupled with attempts to use legislative amendments and other means to improve the system's performance. This loyalty to the system however significantly undermined the strategies of those unions who chose to opt out, as was shown in 1912-13. Or, to put it in the teleological terms favoured by some theorists and activitists, it undermined the unity of the working class.

\section{Employers}

In the wake of the Maritime Strike, employers, triumphant in their deployment of market power, opposed the IC\&A Act. Nor did they have reason to be pleased by its operation. Workers soon discovered how the Act could be used to create unions, to force their recognition, and to haul employers into the Arbitration Court where claims for wages and conditions were subject to binding arbitration. Moreover, in the face of bitter opposition from employers, they sought to use the Court to enforce preference. But, if the employers market power was partly balanced by the rights accorded unions by the arbitration system. the news was not all bad. Typically, the Court's awards recognised, rather than superseded the wages and conditions already paid by good employers - often on the basis of a consensus between the parties. In doing so they effectively ruled out wage competition among employers, preventing the employers on one region being undercut in the pricing of goods and services by those in another. Employers consequently came to use the Court to bring their competitors into line. ${ }^{8}$ Despite the discovery of its uses however, the arbitration system seemed to many employers a vexatious intervention into their private affairs.

But. just as for unions, so for employers circumstances change. If the arbitration system undermined the market power of employers at the time of its greatest strength. so it could provide a shelter from the market strength of unions at times of employer weakness. Employers faced such circumstances after 1906 and again in the period from the last years of World War 1 . until the first post-war recession in 1921. They turned from being opponents to allies of the arbitration system. not least because they discovered its provisions could be used to isolate powerful unions and to ease the substitution of new labour for those on strike. But the support was revocable: employers were to turn against arbitration as the recession of the late twenties deepened into depression.

\section{Outsiders: farmers}

Because of their wide impact, the relationships between unions and employers attracted much more general notice. Of most importance, because of their key role in the economy and their political organization, were farmers. Farmer neutrality. as Holt shows. was essential to the passing of the Act. Equally, an alliance between farmers and employers eventually brought about the system's abolition. Farmer indifference depended on a continuing sense that the arbitration system did not affect them. Initially this indifference could be secured simply by 
excluding agricultural labour from the jurisdiction of the Arbitration Court - and was threatened by any sign of union organization in the sector. Later the situation became more complex. Farmers, together with other actors in the economy, came to understand more clearly the linkages between agriculture, and non-tradeable sectors of the economy. In this more sophisticated understanding, and in the context of a squeeze on farm profits in the twenties, the arbitration system came to appear as a device for raising farm costs.

\section{The wider political context}

Stances toward the arbitration system depended only partly on the Court's performance. Equally important were the wider pattern of political alliances and coalitions in which the participants were involved. Farmers, finding themselves in parliamentary alliances with unionists, acquiesced to compulsory arbitration at the time of its introduction in 1894 and of its rebirth in 1935. but were its most virulent critics in the 1920s. Employers began as opponents of the system, only to find themselves defenders of it, first in alliance with farmers in 1913 and briefly in an alliance with unions in the twenties. Finally however, as part of the price of cementing a larger urban-rural conservative coalition they turned away from the system after 1928. The point is also true of unions. The requirements for creating a viable Labour party led to the moderating of opposition to the arbitration system and compromises among unions on this issue (Olssen, 1987).

\section{The precarious career of the arbitration system}

Tracing out the range of strategies, incentives and constraints bearing on the actors helps make clear the precariousness of the system and especially emphasises the need to explain how it could have survived for so long. The explanation it is also clear, will have to be at two levels: the level of the arbitration system and its particular operations and results, and a broader party political level involving the creation and remaking of governing coalitions. In what follows we look at both of these levels to see how the system worked in ways that allowed its continuance.

In this section our focus is on what got done through the arbitration system - and with what consequences. The broad outlines of our answer are already apparent. The arbitration system was as much about the making of groups and the structuring of relationships among them as it was about the setting of wages or conditions.

The Arbitration Court lay at the centre of the system's operations. Tracing its course over time allows a focus on the process by which the system worked and an understanding of its persistence and its precariousness. The Court's decisions, in intended as well as unintended ways, were the most immediate determinant not only of what happened within the system but the degree of support or antagonism for its operations generated outside of it. Holt's focus on the detail of the Court's operation is therefore extremely important to understanding how the system operated.

\section{$1894-1913$}

Initially the operations of the Court helped to develop the arbitration system and reinforce its own position within it. By following a strategy of levelling up wages and conditions, the Court could encourage newly forming unions without greatly antagonising employers. By steering around the potentially explosive issue of preference, except where employers and unions agreed, the Court avoided an obvious area of contention. In the absence of applications for registration by unions of farm labourers the sensitivities of the rural sector remained unruffled.

By 1908 however, the Court had arrived at its first crisis, which was not be be finally resolved until 1913. The Court's own pattern of decisions and their implications, lay at its heart. Most immediately, the Court's success in generating business, aided by the 'Willis blot', had clogged the conciliation and arbitration procedures, creating numerous irritations for unions and employers alike. These difficulties were largely dealt with by the reforms sponsored by the Minister of Labour, John Miller. The substance of the reforms was however, of less immediate importance than the context in which it occurred. By 1908 the most powerful and best organ- 
ized unions were in active rebellion from the system. while farmers had joined employers in their antagon ism. Legislative reform in this context was a brave act of hope. Its impetus was the desire to maintain the original Liberal coalition of farmers and workers and the institutions this had spawned, at a time when the process of electoral dissolution was already well under way. Not surprisingly, as Holt reports, Miller's reforms were carried out with. little ardent support from right or left (Holt, p. 87). How had this situation come about?

For unions, the Court's decisions came to carry a double message. On the one hand, the Court made union organization simple and guaranteed minimum wages and conditions for union members. On the other hand, it increasingly limited the settlements of strong unions below the levels they thought they could achieve in direct bargaining. The first message led to attempts to extend the jurisdiction of the Court; the second to rebellions against it.

The guarantees offered by the Court provided important incentives for the organization of those most difficult of all workers to organize: agricultural labourers. But the prospect of an agricultural labourers union immediately antagonised farmers. By 1908 the Canterbury Farmers Union had affiliated with the Canterbury Employers Union and demanded of parliamentary candidates that they commit themselves to the repeal of the Act. The heat was only taken out of the issue when the Court finally declined to make an award.

If some unions sought inclusion under the Court's umbrella, others chafed under its restrictions. The Court's decisions, once the initial stage of. 'levelling up' had taken place did not provide unions with a share of their employers' profits and, for some unions, may not even have kept pace with the cost of living. In a time of rising prosperity, and with the increased levels and sophistication of union organization (which in part had been facilitated by the arbitration system) the incentives for strong unions to strike out on their own proved overwhelming. But the Red Feds' breakout, as well as signalling the discontent of some unions, also immediately diminished the support for arbitration of those employers and farmers who had seen in the system, whatever its other faults, a means of preventing strikes.

But if the working of the system precipitated powerful opposition, it also in the end, Holt shows, helped guarantee its continuance. The division of loyalties between unions who benefitted from the system and those who wished to escape its procedures isolated and blunted the challenge from below. Simultaneously the threat of militant labour, and the resources offered by the arbitration system to defeat it. helped cement a new alliance of farmers and employers in the system's support. The resources were partly symbolic - the Red Feds could be portrayed as militants unwilling to work within the rules of the game and their strikes as unjustified - and partly organizational. The system allowed employers to encourage arbitrationist unions in which strike breakers could be enlisted and offered the Court's protection, and it prevented strikers from being assisted financially by unions registered under the Act.

The end result was the continuance of the system - but now under a political coalition of employers and farmers represented by Reform's victory in 1913. The situation is nicely summarised by Holt:

\begin{abstract}
While the arbitration system helped defeat the strikers and destroy the Red Feds in 1912-13. the strikes and the Red Feds helped ensure the survival of arbitration. A majority in the union movement had favoured arbitration all along and the failure of the revolt only reinforced the conviction .... that direct confrontation between labour and capital were ruinous for workingmen. The effect of the Red Fed episode was to turn many farmers. employers and conservatives into champions of arbitration too. The arbitration system had helped isolate the militants and radicals in the union movement, undermine the solidarity of the workers on strike, and legitimise the strike-breaking activities of the employers, farmers. and non-union labour. The very fact that the arbitration system had been so bitterly attacked by the Red Feds rendered it more appealing to those on the right who had formerly been its major critics ... The arbitration system had survived the transition from Seddonism to Masseyism thanks in large measure to the actions of its most virulent opponents (Holt. p. $112-113)$
\end{abstract}

\title{
$1913-1932$
}

The arbitration system was saved in 1913 by a combination of factors. A new supporting coalition of farmers and employers had emerged, a coalition that only five years earlier had clamoured for the system's abolition. But five years is a long time in the life of the arbitration system. Farmers and employers had come to understand things they had not known - more 
importantly, could not have known - in 1908, and they now appreciated what the system could offer them. The resilience of the system, especially the monopolistic and blanket jurisdication of registered unions, was important to its survival. The same ease of registration that had been crucial to the recovery of unionism after 1894 was turned against the challengers; it was as easy to find 15 scabs in 1913 as to find the same number of unionists in earlier years. And, essential to the process was the role of the Massey government, both in terms of astute legislative amendments to buttress the system (the Police Offences Amendment Act and the Labour Disputes Investigation Act) and the use of overwhelming physical coercion.

This latter aspect is a reminder both of the arbitration system's dependence upon various forms of state coercion, of which Massey's cossacks were at one repressive extreme and the routine operation of the system at the other, and of the grim irony that in 1913 a court-based system was in the end saved only by bitter street violence. This raises a key question: how did the system get into such a mess, and what did its chief participants do over the next period to prevent this happening again?

The answer to the first part of our question is apparent from our preceding account. Here, we will formalise it in terms of the state-centred approach outlined earlier. The organizational configuration and overall patterns of activity of the Arbitration Court in the pre- 1913 period gave it no routine way to resolve the problems that lay at the heart of the Red Fed rebellion. Its fair wage policy worked well for first awards, but provided no ready basis for improving wages in subsequent awards. A profit-sharing approach was doubly ruled out by the occupational basis of most awards and the employer hostility it would have provoked. A living wage approach based on the cost of living offered one possible solution. Holt's account makes it clear that, following the Harvester decision, such notions were part of the Court's calculations. But it could not form a systematic basis for wage adjustment before 1913. The information base was inadequate. Just as important, the three yearly renewals of awards would have created a lottery in which the size of a worker's wage increases would be determined by precisely when the award was settled. From the Court's later pronouncements, when it had resolved these problems and adopted a living wage policy, it is evident that these considerations weighed heavily with it. The Court had never accepted jurisdiction over issues of managerial prerogative and labour process control and so was also poorly placed with regard to the other issues which were bound up in the Red Fed rebellion (Olssen, 1987; Richardson, 1987). Consequently the workers involved were led by the structure and operation of the system into patterns of group formation and collective strategies that lay outside the arbitration system.

The second part of our question - how were the system`s participants able to prevent a repetition of 1913 - leads naturally to a further question. Why were the system's participants, especially the Court, unable or unwilling to prevent its political abolition in 1932? Our analysis will suggest a harsh irony. The changes in the organizational configuration of the system and the patterns of activity within it in this period, which helped to prevent a further 1913, led directly to the system's abolition in 1932. And, we note here a curious cycle. The attacks on the system at the end of each of these periods came from those who at the start of the period seemed to have most to gain from it. There appears to be a sense in which the members of the Court. alert to the chief sources of support and opposition, attend to the latter's grievances and devise solutions which anger their erstwhile supporters and lead to their defection.

The Arbitration Court changed its mode of operation radically after 1913. However this did not occur immediately. Although the shock of the Red Fed challenge must have made an institution as politically sensitive as the Court consider how best to secure its future, the weakness and division besetting unions gave the Court some breathing space. For the first time in its career, the Court enjoyed the luxury of the whole-hearted support and approval of politically and industrially dominant coalitions (employers and farmers). The Court - and the Court of Appeal with its ban on unqualified preference in 1916 - consolidated their support with a series of decisions over the next few years that were unfavourable to unions." The Court was only compelled into a reassessment of its approach by the problems of wartime inflation. Like the Red Fed challenge, these exposed the limitations of the Court's procedure. Despite its recommendation to employers to follow its policy of bonuses, the Court, still tied into three year awards, was unable to ensure that wages kept pace with the cost of living. The result was a dramatic increase in industrial militancy and bargaining outside the system by unions who were confident of their own resources and market power. Unions dependent on the system were unable to pursue such options and they became increasingly embittered. 
The arbitration system survived this test because its organizational configuration and pattern of activity changed to deal with these problems. The impetus came from the Government which was weary of the political strife it was getting into in its role of chief industrial mediator, solving the disputes the system could not handle. In 1918, it gave the Court power to amend awards during their currency and to do so on the basis of the cost of living. The Court. given a political lead, took the matter further. Intriguingly, Holt's account shows that in March 1919. the employer representative on the Court was vital in convincing a reluctant judge to give a substantial increase to tradesmen. Encouraged by this show of political and industrial support for such an approach, the Court decided in the following month to introduce Standard Wage Pronouncements (SWPs) and announced that it would issue six monthly bonuses to the SWP rates based on cost of living figures supplied by the Government Statistician.

These developments were crucial to the future development of the arbitration system. In the short term, the introduction of SWPs reassured craft unions that their wages and their status would be preserved by the Court. This was highly significant in view of their growing unhappiness at this time. It shored up the support of craft unions and steered them to strategies oriented around preserving the skill margins established by the SWPs. It also suggested to the militant unions - who were never always and everywhere militant - that the Court might adopt a more flexible approach to cost of living issues. In other words, the changes made possible the raising of certain issues and the adoption of certain strategies that had been previously ruled out by the structure and policies of the Court.

The longer term implications were profound. The use of SWPs created a hierachy of wages based on levels of skill that became the central consideration in all wage-fixing and set strict limits to the kinds of arguments that were relevant in wage-fixing. This consolidated the Court's predominance over Conciliation Councils about which the Court had been concerned in the past. It established the Court finally as a national wage-fixing tribunal, a role it had played to some degree before but was now clearly visible to and accepted by all, including the Court. It operated as a court could be expected to operate, treating all groups the same, locating them within the complex network of relativities it had developed. In doing so, it had solved its pre- 1913 problem. It now knew how to settle any award.

The Government, employers and farmers were presumably pleased with this on the whole. The impetus for restoring the system had come from the first two of these, and although, as Holt suggests, they grumbled a little about specifics, they had overall got what they wanted. But as with so much that is important about the arbitration system, the full implications of the changes were revealed over time. As we have noted earlier, five years is a long time in the life of the arbitration system. By the mid 1920s the economy, especially the exporting sector was in dramatic decline. Farmers clamoured for wage reductions. But when the Court came to consider two awards fundamental to the cost structure of the farm sector, the economic decline of that sector and the rapid decline in the terms of trade were not decisive arguments. In the shearers' award in 1926 and the freezing workers' award in 1927, the Court accepted as decisive arguments based on cost of living and on relativity with other groups of workers. The wheel had come full circle.

The arbitration system now prohibited or rendered futile arguments which farmers saw as crucial, and offered them no ready strategy within the system to remedy this. Their response was to press for political change and for an end to the system. This required a shift from sectoral politics to class politics. The arbitration system was about sectoral interests and alignments. The sectoral interests of employers were well served by the system, farmers believed at their expense, and in some degree in alliance with workers. (Farmers have always believed in what Muldoon called the 'unholy alliance'). Employers were only prepared to abandon that sectoral, advantage and unite with farmers against arbitration in circumstances where class politics eclipsed sectoral alliances. This was achieved in the political realignments between 1927 and 1932.

\section{Conclusions}

Holt's book is a major contribution to the analysis of the role of state and market in the structuring of class in New Zealand. We have tried to make his account more theoretically explicit, emphasising the state centred approach that he takes, but without. we think, departing from the spirit or intent of his work.

The origins of the arbitration system lay less in the advocacy of labour, pressed from outside of parliament, than in the new means of organizing and holding political power embodied in 
the Liberal party and its coalition, coupled with the advocacy of William Pember Reeves. The Industrial Conciliation and Arbitration Act was only one of a large number of measures pushed through parliament by the Liberals. Like the others, it was designed to mobilise and channel the party's constituency of farmers and workers. Changes in the political system, their consequences for who held power and for how that power would be used, are therefore inseparable from an understanding of the origins of the arbitration system.

But once in place, as Holt shows, the system had a career of its own, with consequences quite different from those intended by Reeves. These flowed from the way the Act created new resources for the building of union and employer organizations and for the structuring of relations among them.

4 The resources derived from access to the state's means of administration and coercion, rather than directly from the labour market. They were attractive precisely because they offered the weaker party in the labour market a means of redressing the balance with the stronger.

But the system's survival depended as much on the insurgencies it fostered as on the incentives for conformity it provided. By excluding direct bargaining, it channelled some unions into challenging the system at the same time as it vested the interests of other unions in the system's continuance. By isolating insurgent unions, the system helped undermine the challenges its own structure generated. Unions bound into arbitration actively opposed rebellion, and farmers and employers came to support the system and ensure its survival.

The survival of the system also has to be seen in the larger context of party competition and coalition. At different times parliamentary support for the system was premised on coalitions of farmers and workers, farmers and employers, and after the latter coalition had acted to abolish what it had previously supported, a rebirth brought about by a new farmer and worker electoral coalition represented in the 1935 victory of Labour. This pattern of support and opposition reflected the exigencies of the electoral system and parliamentary coalitions as much as any fixed pattern of sectoral or class interest.

The events constituting the system and explaining its persistence from one period to the next, unfolded in time. From one point of view, they represent possibilities always present in the institutional structure created by the Act. From another, they reveal the creative discovery of strategies by the different parties, as they struggled for advantage within and sometimes, outside of the system. While both views are necessary, the second offers the more helpful starting place. Institutional structures, their boundaries, resources and crucial relationships are always as much discovered over time, as known all at once. The point is as true for observers and analysts as it is for participants. Getting to know the set of relationships that underpins and explains the events being analysed requires close attention to how those events are related across time. Consequently, narrative and structural analysis are necessarily intertwined, despite the attempts made by some historians and social scientists to hive off one or other as their special province.

Because structures persist, there is an important sense in which events can repeat themselves. The events of 1951 are not so dissimilar from those of $1912 / 13$; and the pattern of labour weakness on the shop-floor, coupled with an important degree of political influence, is as useful a characterisation of the situation underpinning the 1987 Labour Relations Act, as of the 1890 s. Less controversially, the legacies of union structure and employer-union relations have significantly shaped the working of other New Zealand institutions. But the real contemporaneity of Holt's book lies less in the legacies it describes than in its approach: the careful blending of narrative and analysis to uncover the working of a key New Zealand institution. We are all in his debt.

\section{References}

Castles F (1985) The working class and welfare Sydney, Allen \& Unwin.

Hirschman A O Exit voice and loyalty: responses to decline in firms, organizations and states Cambridge Mass., Harvard University Press.

Holt J (1976) The political origins of compulsory arbitration in New Zealand New Zealand Journal of History 10 (2): 99-111.

Holt J (1986) Compulsory arbitration in New Zealand: the first forty years Auckland. Auckland University Press. 
Lipson L (1948) The politics of equality Chicago. University of Chicago Press.

Martin J (1987) Arbitration: the sheepowners and the shearers New Zealand journal of industrial relations (this issue).

Offe C (1981) The attribution of public status to interest groups: observations on the West German case In Berger S (Ed) Organizing interests in Western Europe Cambridge, Cambridge University Press.

Olson M (1965) The logic of collective action Cambridge Mass: Harvard University Press.

Olssen E (1987) The origins of the Labour party: a reconsideration New Zealand Journal of History 21 (2): 79-96.

Richardson L (1981) Parties and political change in W H Oliver (Ed) The Oxford History of New Zealand Wellington, Oxford University Press.

Richardson L (1987) Coalminers, arbitration and the workplace New Zealand journal of industrial relations (this issue).

Sinclair K (1965) William Pember Reeves: New Zealand Fabian Oxford, Clarendon Press.

Skocpol T (1985) Bringing the state back in: strategies of analysis in current research IN Evans P. Skocpol T and Rueschemeyer (Eds) Bringing the state back in New York, Cambridge University Press.

Williams A (1977) Industrial militancy in New Zealand: the contributing influence of the Industrial Conciliation and Arbitration Act, and its administration, 1894-1908 PhD thesis Massey University, Palmerston North. 